\title{
PI signal transduction and ubiquitination respond to dehydration stress in the red seaweed Gloiopeltis furcata under successive tidal cycles
}

Shun Liu ${ }^{1,2,3}$, Zi-Min Hu ${ }^{1,2^{*}}$, Quansheng Zhang ${ }^{4}$, Xiaogi Yang ${ }^{1,2,3}$, Alan T. Critchley ${ }^{5}$ and Delin Duan ${ }^{1,2^{*}}$ (D)

\begin{abstract}
Background: Intermittent dehydration caused by tidal changes is one of the most important abiotic factors that intertidal seaweeds must cope with in order to retain normal growth and reproduction. However, the underlying molecular mechanisms for the adaptation of red seaweeds to repeated dehydration-rehydration cycles remain poorly understood.

Results: We chose the red seaweed Gloiopeltis furcata as a model and simulated natural tidal changes with two consecutive dehydration-rehydration cycles occurring over $24 \mathrm{~h}$ in order to gain insight into key molecular pathways and regulation of genes which are associated with dehydration tolerance. Transcription sequencing assembled 32,681 uni-genes (GC content $=55.32 \%$ ), of which 12,813 were annotated. Weighted gene co-expression network analysis (WGCNA) divided all transcripts into 20 modules, with Coral2 identified as the key module anchoring dehydration-induced genes. Pathways enriched analysis indicated that the ubiquitin-mediated proteolysis pathway (UPP) and phosphatidylinositol (PI) signaling system were crucial for a successful response in G. furcata. Network-establishing and quantitative reverse transcription PCR (qRT-PCR) suggested that genes encoding ubiquitin-protein ligase E3 (E3-1), SUMO-activating enzyme sub-unit 2 (SAE2), calmodulin (CaM) and inositol-1,3,4trisphosphate 5/6-kinase (ITPK) were the hub genes which responded positively to two successive dehydration treatments. Network-based interactions with hub genes indicated that transcription factor (e.g. TFIID), RNA modification (e.g. DEAH) and osmotic adjustment (e.g. MIP, ABC1, Bam1) were related to these two pathways.

Conclusions: RNA sequencing-based evidence from G. furcata enriched the informational database for intertidal red seaweeds which face periodic dehydration stress during the low tide period. This provided insights into an increased understanding of how ubiquitin-mediated proteolysis and the phosphatidylinositol signaling system help seaweeds responding to dehydration-rehydration cycles.
\end{abstract}

Keywords: Seaweed, Dehydration, Ubiquitination, Phosphatidylinositol signaling system, Weighted gene coexpression network analysis

\footnotetext{
* Correspondence: huzm@qdio.ac.cn; dlduan@qdio.ac.cn

${ }^{1}$ Key Laboratory of Experimental Marine Biology, Center for Ocean

Mega-Science, Institute of Oceanology, Chinese Academy of Sciences,

Qingdao 266071, People's Republic of China

Full list of author information is available at the end of the article
}

(c) The Author(s). 2019 Open Access This article is distributed under the terms of the Creative Commons Attribution 4.0 International License (http://creativecommons.org/licenses/by/4.0/), which permits unrestricted use, distribution, and reproduction in any medium, provided you give appropriate credit to the original author(s) and the source, provide a link to the Creative Commons license, and indicate if changes were made. The Creative Commons Public Domain Dedication waiver (http://creativecommons.org/publicdomain/zero/1.0/) applies to the data made available in this article, unless otherwise stated. 


\section{Background}

As the boundary between land and sea, the intertidal zone has a unique ecological environment caused by the changing of tides and period of exposure due to the amplitude between spring and neap tides. Seaweeds growing in the intertidal zone are subject to sometimes extreme abiotic stresses during low tide, such as dehydration, strong solar irradiance and fluctuating temperature [1, 2]. Among all of these stressors, dehydration of the algal tissues is one of the most important limitations determining the upper and lower vertical distributions of intertidal seaweeds [3, 4]. Water loss can cause osmotic stress, mechanical damage to membrane systems and intra-cellular oxidative stresses which are induced by excessive reactive oxygen species (ROS) [2, 4-6]. In addition, dehydration can affect the main physiological and biochemical processes in seaweeds, including photosynthesis, protein synthesis and energy metabolism $[4,5,7,8]$. Therefore, it is of great significance to study both the adaptive and tolerance mechanisms of seaweeds when responding to water deficit stress caused by exposure.

When facing desiccation stress, plant can usually activate rapid transduction of environmental stress signals and tolerance-related biochemical regulatory mechanisms [9]. Some studies on dehydration mechanisms in various seaweeds illustrated that increased antioxidant enzymes and components associated with detoxification were responsible for eliminating over-production of ROS $[2,4,5,10]$. Meanwhile, the accumulation of compatible solutes can regulate cellular osmotic pressure and protect seaweed tissues during the dehydration process [11-13]. Other studies have paid much attention to the effect of dehydration on photosynthetic activity and cyclic electron flow $[4,8,14,15]$. Nevertheless, some aspects relating to the actual mechanisms of dehydration tolerance are still unsolved. For example, the studies mentioned above did not uncover the associated upstream regulation and signal transduction systems. Recently, some studies illustrated that certain algae such as red seaweed Pyropia orbicularis and streptophyte green alga Klebsormidium share some common responding mechanisms with mosses or higher plants during water loss stress $[8,16,17]$. These findings inspired us to explore potential molecular pathways responsive for dehydration tolerance that have been previously overlooked in seaweeds. For example, the ubiquitin system is crucial for higher plants in their responses to drought stress [18, 19], but still poorly studied in seaweeds.

Gloiopeltis furcata (Rhodophyta) is a marine macroalga which occurs abundantly on the upper, rocky intertidal zone in the North Pacific coast [20, 21]. It has an important economic value in food, textile and traditional medicine [22]. Extracts of G. furcata have a variety of proposed functions such as cancer prevention and blood anti-coagulation [23-25]. Ecologically, seaweeds inhabiting the upper interidal zone (exposed for the greatest duration) are believed to have considerable potential to tolerate dehydration $[3,4]$. In accordance with this expectation, G. furcata is indeed able to tolerate water loss for more than $72 \mathrm{~h}$, despite nearly $80 \%$ of tissue water content being lost during low tide [26]. More specifically, even with a tissue water content as low as $6 \%, G$. furcata could recover photosynthetic activity after complete submergence and rehydration [26]. Recently, G. furcata was reported to have a high $\mathrm{O}^{2}$-radical-scavenging activity [27]. These results indicated that G. furcata was an ideal model for studying dehydrationinduced acclimation strategies of red seaweeds in intertidal ecosystems.

In this study, we chose G. furcata as research material and simulated two dehydration-rehydration cycles in the laboratory (Fig. 1), with goals to find the key pathways and genes related to dehydration stress by using RNAsequencing and weighted gene co-expression network analysis (WGCNA). Considering that natural tidal changes are continuously cyclic, continuous periodic treatments can help us to better understand the responding during dehydration stress. The results provide valuable insights for understanding the molecular mechanisms associated with dehydration of intertidal seaweeds.

\section{Results}

\section{Overlook of transcriptome assembly}

After assembly and filtration (see Materials and Methods), all clean reads were assembled into 32,681 uni-genes with an average length of $799 \mathrm{bp}$, and N50 was $1238 \mathrm{bp}$ (Table 1). The average GC content of the uni-genes was 55.32\% (Table 1). Twenty-four cDNA libraries were generated by RNA sequencing, and the number of reads (after filtration, see Materials and Methods) per library ranged from $21.90 \mathrm{M}$ to $34.58 \mathrm{M}$ (Additional file 1: Table S1). Statistical analyses of unigenes expression levels in each sample showed that most of uni-genes were in the range of 0.5-5 RPKM (reads per kilobase of exon region per million mapable reads) and 5-100 RPKM. Approximately, 61\% of expressed uni-genes had RPKM values $\leq 5$, and $39 \%$ had RPKM values $\geq 5$ (Additional file 2: Fig. S1). BLAST results indicated that $12,813(39.2 \%)$ uni-genes were annotated into at least one of the following databases: the Kyoto Encyclopedia of Genes and Genomes database (KEGG) and Clusters of Orthologous Groups of proteins (KOG), NCBI non-redundant protein sequences $(\mathrm{Nr})$ and Swissprot, 4815 uni-genes were annotated into all of these databases (Additional file 3: Fig. S2). 


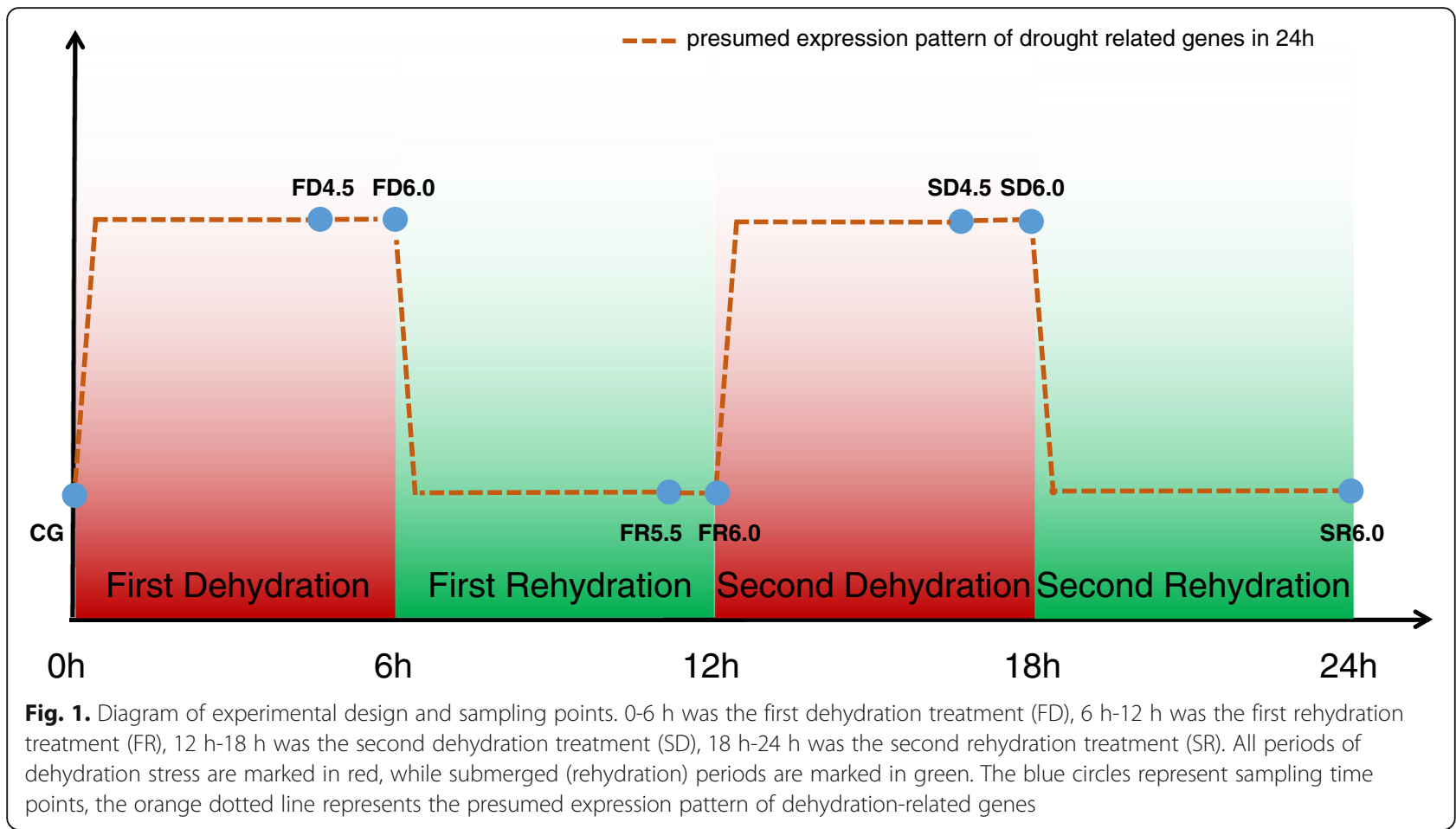

Fifteen uni-genes were selected for quantitative reverse transcription PCR (qRT-PCR) analysis in order to validate the quality of RNA-Seq data and $75 \%$ of which had a correlation coefficient $\geq 0.8$, suggesting a strong consistency between quantitative results and transcriptome data (Additional file 4: Table S2). Such a correlation between RNA-Seq and qRT-PCR confirmed the high reliability of transcriptomic profiling data.

\section{Modules associated with dehydration tolerance by WGCNA}

According to the filter standard (see Materials and Methods), 4876 uni-genes were removed. A topological overlap matrix (TOM) was generated using a set of 27, 805 uni-genes for WGCNA (Additional file 5: Fig. S3). After a dynamic tree cut and merging, twenty modules were identified and designated by different colors, with gene numbers ranging from 84 (Deeppink) to 5513

Table 1 Overview of G. furcata transcriptome information

\begin{tabular}{ll}
\hline Item & Number \\
\hline Total assembled bases & $26,117,344$ \\
Total uni-genes identified & 32,681 \\
GC \% & 55.32 \\
N50 (bp) & 1238 \\
Max length (bp) & 12,627 \\
Min length (bp) & 201 \\
Average length (bp) & 799 \\
\hline
\end{tabular}

(Coral2) (Fig. 2a and b). Module-trait relationships and eigengenes expressions of each module indicated that Coral 2 was characterized by two clear fluctuations, in accordance with the two cyclic treatments of dehydration (Fig. $2 b$ and c). Specifically, the expression patterns of genes grouped into Coral2 were up-regulated during two dehydration treatments, and down-regulated during rehydration (Fig. 2b and c). Although the gene expression at SD4.5 did not show significant increase, all other time points were in line with expectations (Fig. 2c). The Coral2 module was thus chosen for the following analysis.

\section{Pathway enrichment analysis of Coral2 provided insight into phosphatidylinositol signal transduction and ubiquitin mediated proteolysis}

5513 uni-genes were grouped into the Coral2 module, and the functional pathways were characterized in Coral2 using GO analysis and KEGG enrichment study. A large number of uni-genes in Coral2 were involved in genetic and environmental information processing and metabolism. Statistics on GO terms of uni-genes in Coral2 showed that many uni-genes involved in cellular process and metabolic process, and the molecular function of binding and catalytic activity had the largest number of uni-genes (Additional file 6: Fig. S4). KEGG pathway enrichment analysis revealed that Coral2 was enriched $(P<0.05)$ in the ubiquitin mediated proteolysis pathway (UPP), protein export, phosphatidylinositol signaling system (PI signal system), and both starch and 


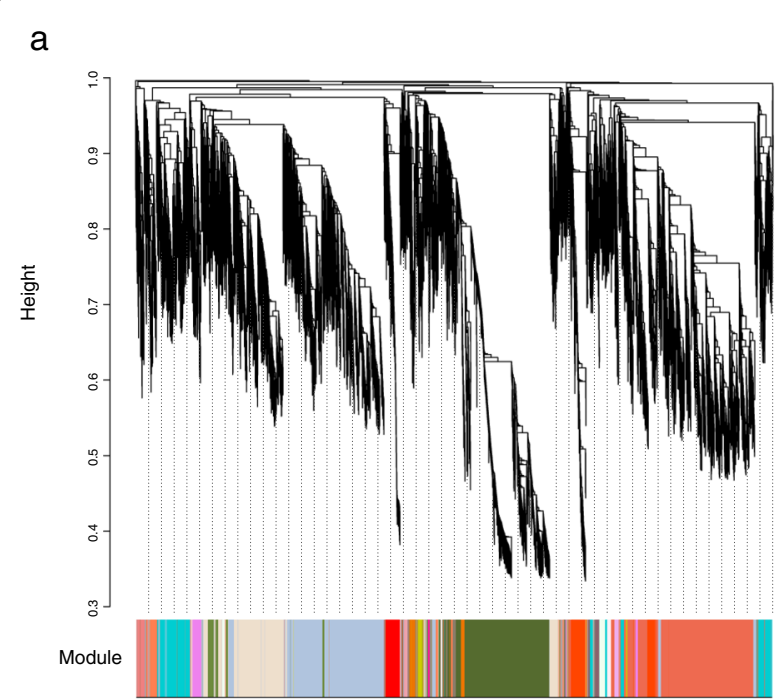

\section{b}
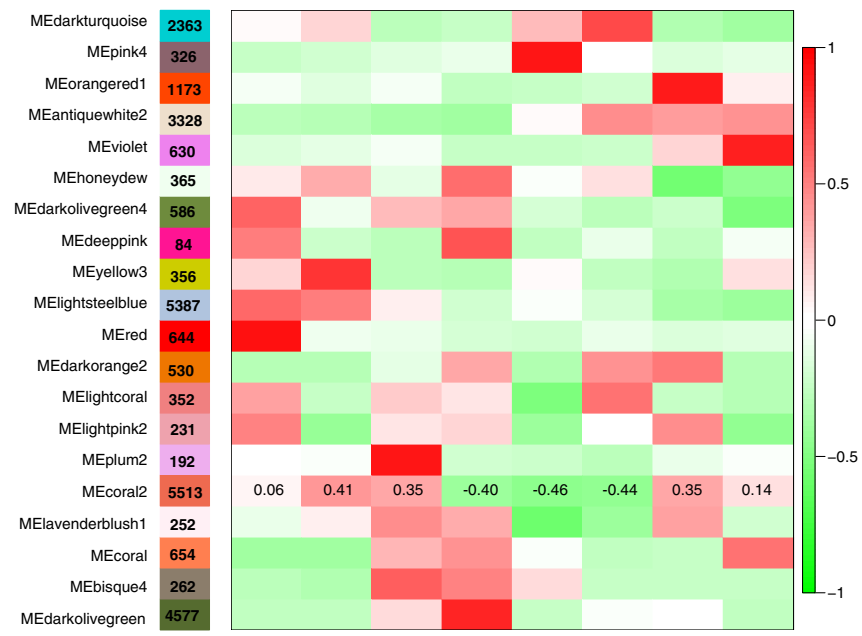

CG FD 4.5 FD 6.0 FR 5.5 FR 6.0 SD 4.5 SD 6.0 SR 6.0

C

d
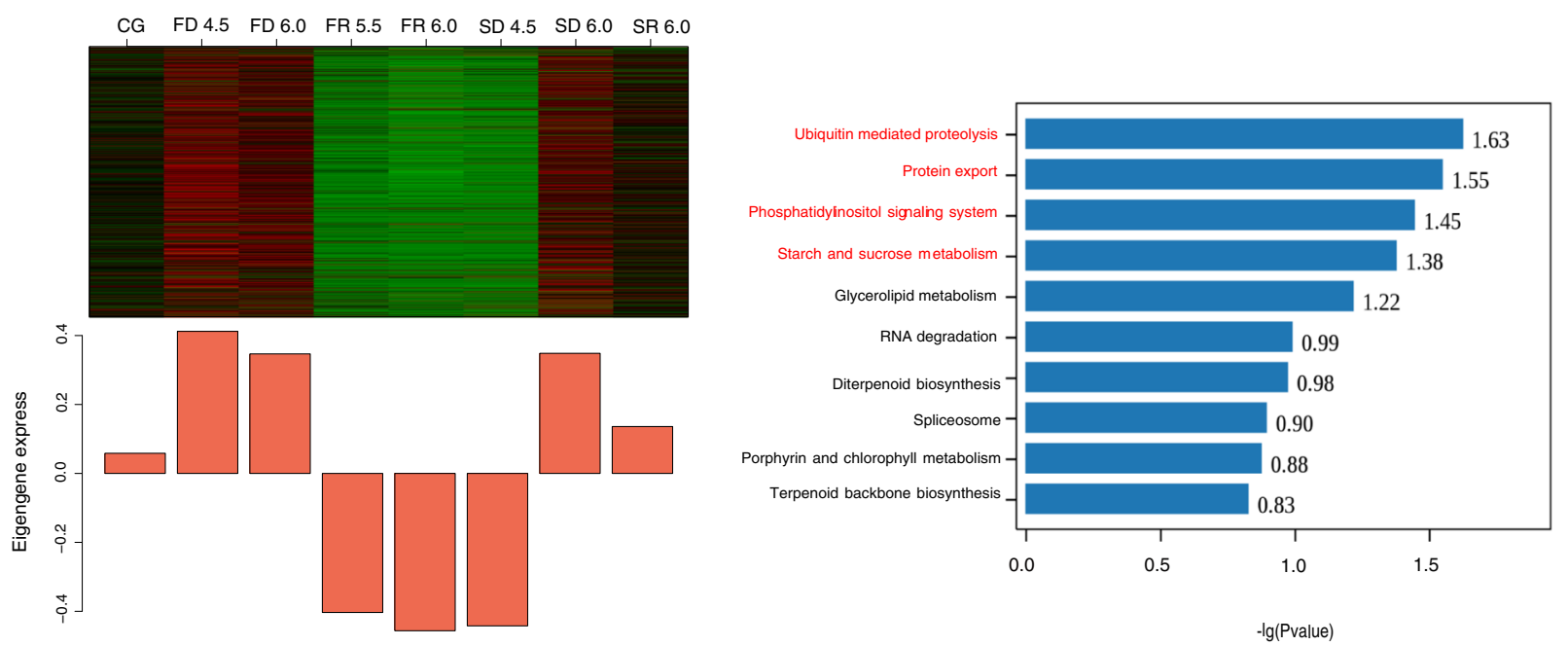

Fig. 2. WGCNA of drought-associated genes in G. furcata. a: Clustering dendrogram and modules for 27805 uni-genes. Each gene is represented by a leaf in the tree, the y axis represents network distance, as determined by topological overlap (TO), different colors shows module membership after being merged. b: Module-trait relationships. Colors on the left represent twenty modules and the numbers of uni-genes were written in each module. A heat-map shows the module eigen-gene (ME) correlations to traits (eight samples for experiment). Numbers in the Coral2 analysis reported the correlation coefficients for the ME-trait relationship. c: Eigengene expression profile for Coral2 module. The bar-plot reported eigengene expression at each sampling point. For the heat-map, rows corresponded to genes, columns to samples, the green color represented under-expressed, the red denoted over-expressed. $\mathbf{d}$ : Top ten statistics of KEGG pathway enrichment. The names of those enriched pathways with $P<0.05$ were marked in red

sucrose metabolism (Fig. 2c, Table 2, Additional file 7: Table S3). Many uni-genes belonging to the UPP and PI signals had $a \geq 1.5$ fold change of RPKM value during drought stress, with very low expressions during rehydration (Table 2). We subsequently constructed coexpression networks to look for hub genes in these two pathways, considering that the function of UPP in dehydration response may have been neglected in seaweeds and the PI signal pathway still has not been studied clearly.

\section{Identification of key genes related to UPP}

A UPP network was built by UPP-related genes and their co-expression genes in Coral2. The network contained 857 nodes and 1783 edges (Fig. 3a and Additional file 8: Table S4). Eight ubiquitin-related genes exhibiting high connectivity $(>100)$ were indicated in red, and four with interactions $\geq 150$ were considered as large hubs (Fig. 3a). These large hubs were annotated as one unnamed protein product (Gf19264/UN1) and three E3 ubiquitin ligase (Gf27969/E3-1, Gf16090/E3-2, 
Table 2 Uni-genes annotated into ubiquitin-mediated proteolysis and phosphatidylinositol signaling system

\begin{tabular}{|c|c|c|c|c|c|c|c|c|c|c|}
\hline \multirow[t]{2}{*}{ Gene ID } & \multicolumn{8}{|c|}{ Fold change } & \multirow[t]{2}{*}{ KME } & \multirow[t]{2}{*}{ Annotation } \\
\hline & CG & FD4.5 & FD6.0 & FR5.5 & FR6.0 & SD4.5 & SD6.0 & SR6.0 & & \\
\hline \multicolumn{11}{|c|}{ Ubiquitin mediated proteolysis } \\
\hline Gf07512 & 1.00 & 1.62 & 1.68 & 0.30 & 0.00 & 0.03 & 1.68 & 1.33 & 0.99 & Transcription elongation factor B polypeptide \\
\hline Gf18542 & 1.00 & 1.45 & 1.60 & 0.18 & 0.00 & 0.05 & 1.43 & 0.91 & 0.99 & RING-box protein 1 \\
\hline Gf32620 & 1.00 & 1.24 & 0.99 & 0.00 & 0.00 & 0.00 & 1.24 & 0.96 & 0.97 & Histone deacetylase complex subunit Cti6 \\
\hline Gf16090 & 1.00 & 2.43 & 2.21 & 0.14 & 0.00 & 0.00 & 1.73 & 1.09 & 0.97 & E3 ubiquitin-protein ligase TRIP12 \\
\hline Gf27969 & 1.00 & 1.76 & 1.70 & 0.00 & 0.00 & 0.00 & 1.09 & 0.95 & 0.97 & Ubiquitin-protein ligase E3 \\
\hline Gf18536 & 1.00 & 1.62 & 1.50 & 0.19 & 0.00 & 0.03 & 1.00 & 1.01 & 0.97 & E3 ubiquitin-protein ligase UPL3 \\
\hline Gf08625 & 1.00 & 3.30 & 3.00 & 0.08 & 0.00 & 0.15 & 2.84 & 2.12 & 0.97 & Elogin binding protein-like protein, partial \\
\hline Gf19266 & 1.00 & 1.84 & 1.28 & 0.00 & 0.00 & 0.00 & 1.20 & 1.41 & 0.96 & Unnamed protein product \\
\hline Gf18480 & 1.00 & 1.58 & 2.30 & 0.00 & 0.00 & 0.00 & 2.00 & 1.23 & 0.96 & TPR repeat-containing protein \\
\hline Gf13903 & 1.00 & 1.33 & 1.02 & 0.48 & 0.40 & 0.45 & 1.21 & 0.76 & 0.95 & Peptidyl-prolyl cis-trans isomerase-like 2 \\
\hline Gf19264 & 1.00 & 2.90 & 1.74 & 0.20 & 0.00 & 0.02 & 1.70 & 1.37 & 0.94 & Unnamed protein product \\
\hline Gf30775 & 1.00 & 3.18 & 1.68 & 0.05 & 0.00 & 0.06 & 2.70 & 1.61 & 0.94 & ERAD-associated E3 ubiquitin-protein ligase \\
\hline Gf14989 & 1.00 & 1.92 & 1.81 & 0.00 & 0.00 & 0.00 & 0.88 & 1.50 & 0.92 & Unnamed protein product \\
\hline Gf18742 & 1.00 & 0.97 & 1.45 & 0.00 & 0.00 & 0.07 & 1.57 & 1.43 & 0.92 & Ubiquitin-activating enzyme E1 \\
\hline Gf19263 & 1.00 & 2.34 & 1.16 & 0.01 & 0.00 & 0.00 & 1.07 & 1.12 & 0.91 & SUMO-activating enzyme subunit 2 \\
\hline Gf19265 & 1.00 & 2.29 & 0.74 & 0.00 & 0.00 & 0.00 & 1.25 & 1.03 & 0.87 & SUMO-activating enzyme subunit 2 \\
\hline Gf11232 & 1.00 & 1.50 & 2.06 & 0.83 & 0.00 & 0.12 & 1.27 & 1.42 & 0.89 & Ubiquitin-conjugating enzyme E2 34-like \\
\hline Gf06247 & 1.00 & 1.73 & 5.96 & 0.11 & 0.00 & 0.00 & 4.01 & 4.29 & 0.78 & E3 ubiquitin-protein ligase \\
\hline Gf10562 & 1.00 & 1.73 & 1.45 & 0.46 & 0.32 & 0.40 & 0.56 & 1.69 & 0.75 & Ubiquitin carrier protein \\
\hline \multicolumn{11}{|c|}{ Phosphatidylinositol signaling system } \\
\hline Gf03841 & 1.00 & 0.92 & 0.94 & 1.18 & 1.17 & 1.17 & 1.06 & 0.92 & -0.87 & $\mathrm{IP}_{6}, \mathrm{PP}-\mathrm{IP}_{5}$ or $\mathrm{IP}_{7}$ kinase \\
\hline Gf07443 & 1.00 & 2.23 & 1.62 & 0.00 & 0.00 & 0.01 & 1.62 & 1.82 & 0.96 & Calmodulin \\
\hline Gf08993 & 1.00 & 2.27 & 3.21 & 0.03 & 0.00 & 0.00 & 2.39 & 3.03 & 0.91 & $3^{\prime}\left(2^{\prime}\right), 5^{\prime}$-bisphosphate nucleotidase, SAL3 \\
\hline Gf13982 & 1.00 & 1.22 & 0.99 & 0.55 & 0.81 & 0.79 & 1.02 & 0.71 & 0.74 & Inositol-hexakisphosphate kinase \\
\hline Gf14233 & 1.00 & 1.16 & 1.43 & 0.26 & 0.00 & 0.12 & 1.03 & 0.84 & 0.96 & Phospholipase C (by KO-ID) \\
\hline Gf18777 & 1.00 & 4.85 & 1.84 & 0.00 & 0.00 & 0.00 & 1.83 & 1.45 & 0.82 & Inositol-1,3,4-trisphosphate 5/6-kinase \\
\hline Gf30993 & 1.00 & 0.71 & 0.60 & 0.69 & 0.75 & 0.70 & 0.92 & 0.87 & 0.19 & 3 (2) -bisphosphate nucleotidase \\
\hline Gf31439 & 1.00 & 1.44 & 1.08 & 0.69 & 0.17 & 0.33 & 0.95 & 0.21 & 0.72 & Calmodulin 1 \\
\hline
\end{tabular}

The expression level of the genes were shown as fold changes of RPKM comparing to CG. Any fold change higher than 1.5 in four dehydration treatments (FD 4.5, FD6.0, SD4.5, SD6.0) considered as significant increases and used bold type

Gf18536/E3-3) (Fig. 3a and Additional file 8: Table S4). Four other mid-size hubs $(100<$ degree $<150)$ were Gf19263 (SUMO-activating enzyme sub-unit 2/SAE2), Gf19266 (unnamed protein product/UN2), Gf08625 (elogin-binding protein-like protein/EBP) and Gf18542 (RING-box protein 1/E3-RBX) (Fig. 3a). Amongst these mid-size hubs, SAE2 was related to the small ubiquitinrelated modifier (SUMO) conjunction. E3-RBX was also one kind of E3 with a RING-box domain. Thus, four of the eight hubs in the UPP network encoded for different E3 ligases and interacted with 589 nodes (Fig. 3a).

Nodes with at least four neighbors within one distance were extracted, in order to investigate if there was a common up-stream regulator or downstream substrate for the hub genes in UPP. In addition to hub genes, 128 nodes were selected and colored yellow (Fig. 3a). We focused on nine genes according to their descriptions, and extracted them with the hub genes to built a fine-scale sub-network. (Fig. 3b and Additional file 8: Table S4). We found seven genes involved in genetic information processing, two genes encoded for sub-units 2 and 6 of the transcription factor TFIID (Gf03506/TFIID2, Gf26104/TFIID6); one gene encoded the alpha sub-unit of transcription initiation factor IIE (Gf17133/TFIIE by $\mathrm{KO} I D)$ and one gene encoded for the zinc-finger domain containing protein (Gf31441/ZFP) (Fig. 3b and Table 3); three othergenes were involved in RNA processing, such as Gf06149 (exosome component 4-like 


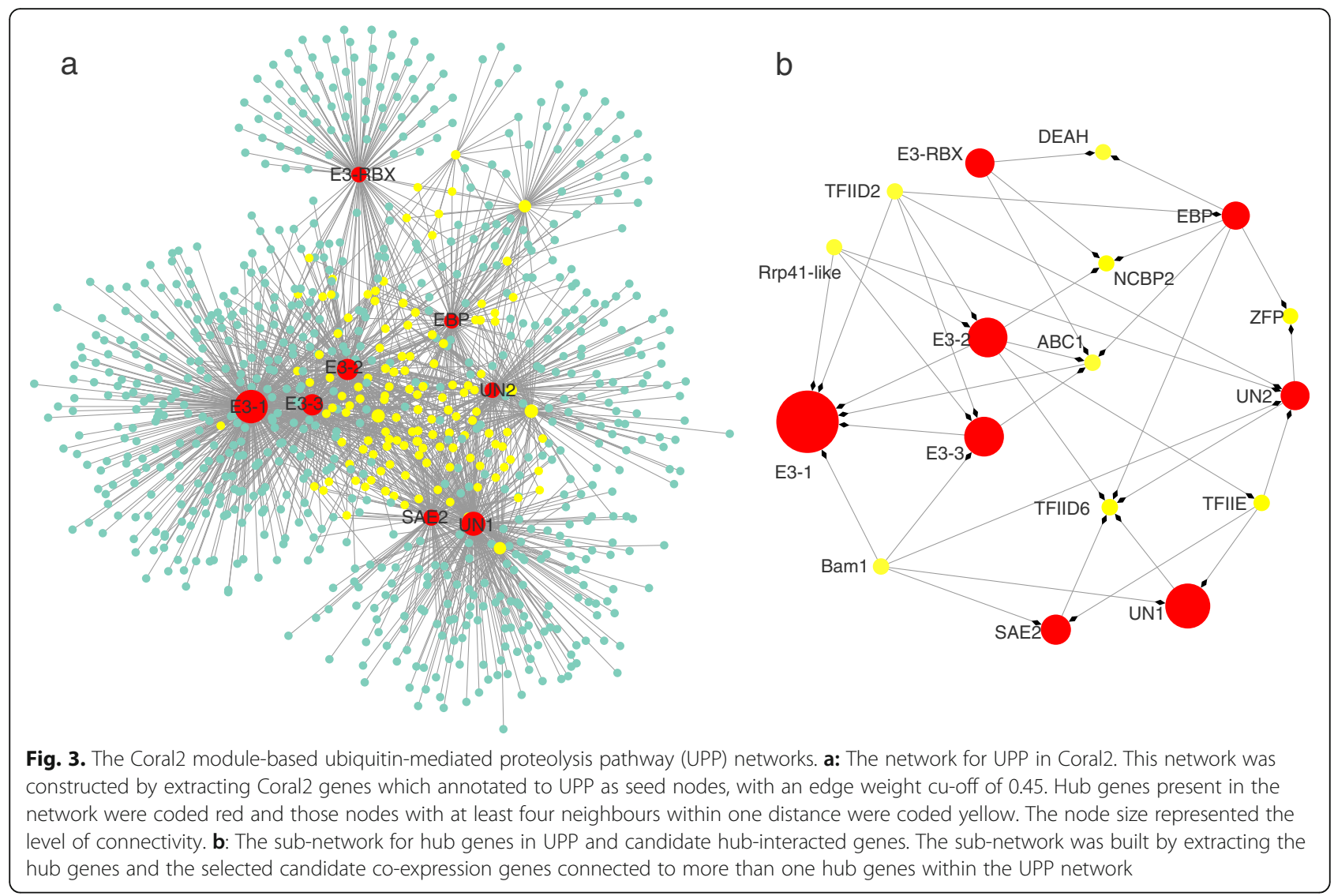

/Rrp41-like), Gf30426 (nuclear cap-binding protein subunit 2/NCBP2), Gf32444 (DEAH-box RNA helicase/ DEAH) (Fig. 3b and Table 3). Moreover, Gf24243 (kin $(\mathrm{ABC} 1) / \mathrm{ABC} 1$ ) and Gf12536 (Beta amylase/Bam1) relating to osmotic regulation also interacted with hub genes in UPP (Fig. 3b and Table 3).

\section{Identification of key genes related to PI signal transduction}

The Coral2 module-based co-expression network for PI signal transduction indicated that the PI signal network contained 1029 nodes and 1433 edges (Fig. 4a and Additional file 9: Table S5). Four large hubs such as Gf07443

Table 3 Candidate hub-interacted uni-genes responsive to desiccation in the UPP and PI signal sub-network

\begin{tabular}{|c|c|c|c|}
\hline Genes & Network & Description & KEGG pathway \\
\hline \multicolumn{4}{|c|}{ Genes participate in genetic information processing } \\
\hline Gf06149 & $C N$ & Exosome component 4-like Rrp41-like & ko03018//RNA degradation \\
\hline Gf03506 & CN & Transcription factor TFIID sub-unit D2 & ko03022//Basal transcription factors \\
\hline Gf32444 & $\mathrm{CN}$ & DEAH-box RNA helicase & - \\
\hline Gf26104 & UPP & Transcription factor TFIID sub-unit 6 & ko03022//Basal transcription factors \\
\hline Gf30426 & UPP & Nuclear cap-binding protein sub-unit 2 & $\begin{array}{l}\text { ko03040//Spliceosome; } \\
\text { ko03013//RNA transport }\end{array}$ \\
\hline Gf31441 & UPP & Zinc-finger domain containing protein & - \\
\hline Gf17133 & UPP & Transcription factor TFIIE (by KO-ID) & ko03022//Basal transcription factors \\
\hline \multicolumn{4}{|c|}{ Genes related to osmotic regulate } \\
\hline Gf12536 & $\mathrm{CN}$ & Beta amylase, Bam1 & ko00500//Starch and sucrose metabolism \\
\hline Gf24243 & $\mathrm{CN}$ & $\operatorname{Kin}(A B C 1)$ & - \\
\hline Gf25392 & $\mathrm{Pl}$ & Major intrinsic protein & - \\
\hline
\end{tabular}




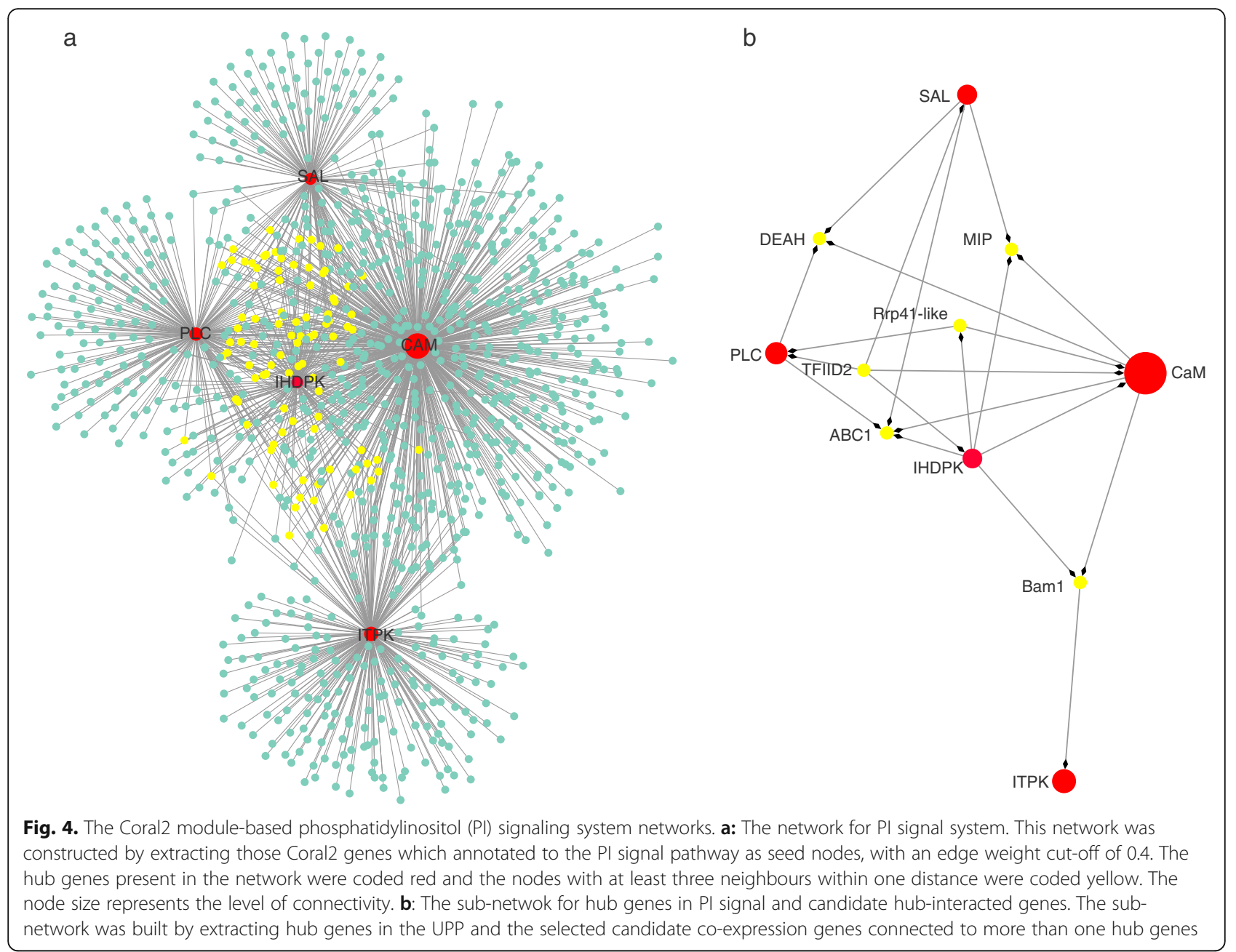

(calmodulin/CaM), Gf18777 (inositol-1,3,4-trisphosphate 5/6-kinase/ITPK), Gf08993 (3'(2'), 5'-bisphosphate nucleotidase/SAL) and Gf14233 (phospholipase C/PLC by KO ID) were identified in the PI network (Fig. 4a). One mid-size hub was Gf03841(inositol hexakisphosphate $\left(\mathrm{IP}_{6}\right)$ and diphosphoinositol-pentakisphosphate (PP-IP 5 or $\mathrm{IP}_{7}$ ) kinase/IHDPK)(Fig. 4a). Among these hubs, $\mathrm{CaM}$, served as a calcium receptor protein, which had the highest connectivity (Fig. 4a). ITPK and SAL not only participated in the phosphatidylinositol signaling system but also in inositol phosphate metabolism (Additional file 9: Table S5).

Ninety-three nodes (except hub genes) with at least three neighbors within one distance were colored yellow in order to find the potentially common interacted genes with hubs (Fig. 4a). Six of them were chosen to build the sub-network (Fig. 4b and Additional file 9: Table S5). Surprisingly, five of these also had co-expression with hub genes in the UPP network, such as Rrp41-like, DEAH, ABC1, Bam1 and TFIID2 (Figs. $3 \mathrm{~b}$ and $4 \mathrm{~b}$ and Table 3). Bam1 was also considered to play a key role in the pathway of starch and sucrose metabolism which was enriched in Coral2 (Additional file 7: Table S3). Gf25392 (major intrinsic protein /MIP), one kind of aquaporin $(\mathrm{AQP})$ that regulates cellular water balance under desiccation conditions, was also found to have some interactions with the PI network hub genes (Fig. $4 b)$.

\section{Expression patterns of four candidate drought-related hub genes}

Combining the fold changes of the RPKM value, the result of co-expression networks and the annotations of genes, we chose E3-1, SAE2, CaM, ITPK as candidate dehydration-responsive genes, and identified their transcriptional expression with qRT-PCR. As shown in Fig. 5 , expression patterns of four hub genes demonstrated their positive responses to dehydration stress. CaM, E31 and SAE2 genes all showed increases during first dehydration and was down-regulated when submerged (Fig. 5). The expression patterns of the second simulated low tide cycle were not exactly the same as the first. 


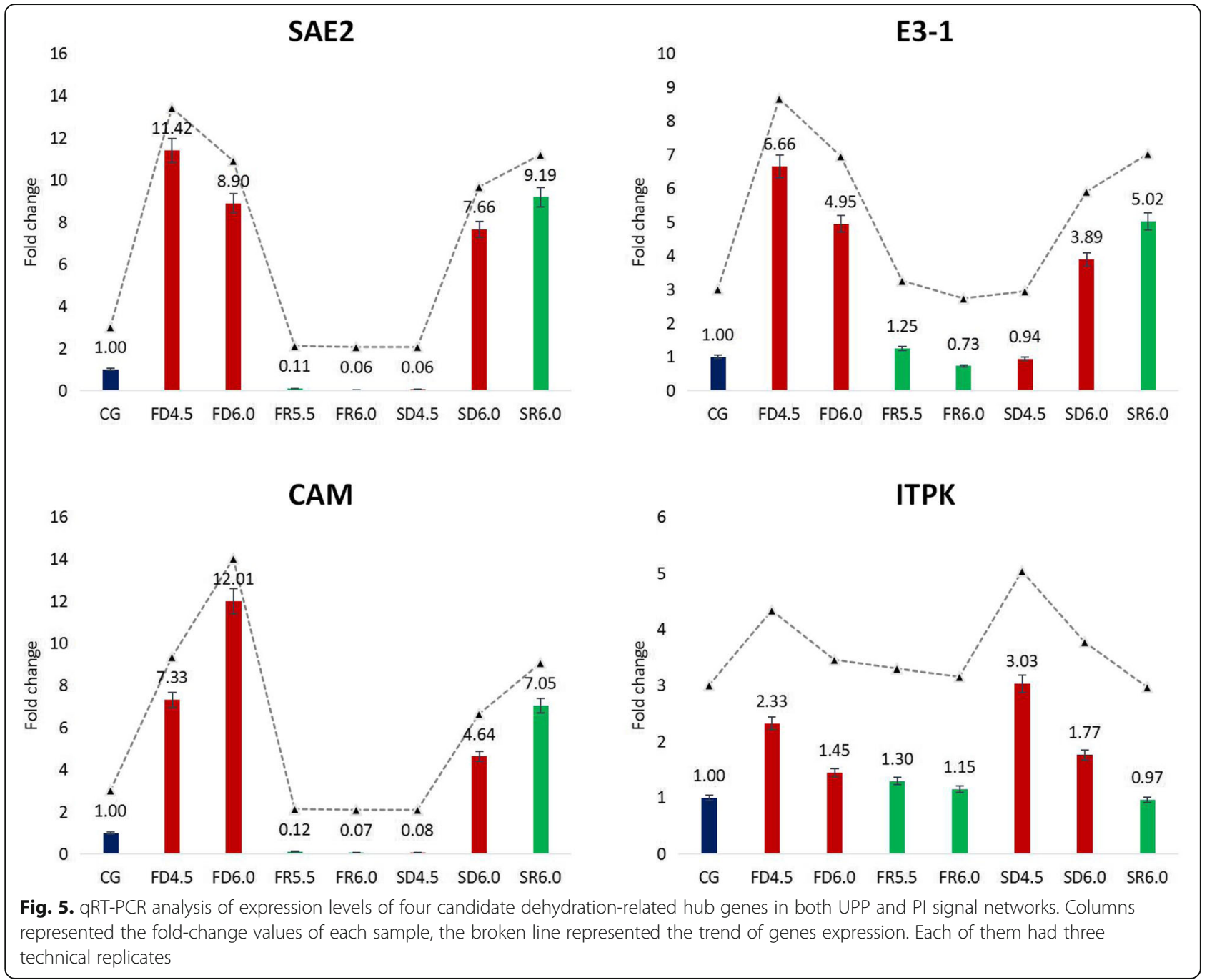

Specifically, the expression levels of CaM, E3-1 and SAE2 genes increased at FD4.5 during the first cycle, but began to rise at SD6.0 during the second cycle, and the fold changes at SD6.0 were lower than at FD4.5 or FD6.0 (Fig. 5). These three genes were all downregulated during first rehydration, especially SAE2 and CaM almost reduced to zero at FD4.5 and FD6.0. However, they did not show downtrends at SR6.0. ITPK was up-regulated at four time points during dehydration treatment, peaked at FD4.5 and SD4.5, and reduced to almost normal level after rehydration (Fig. 5).

\section{Discussion}

Post-translation modifications mediated dehydration response in G. furcata, E3 and SAE2 were the key genes induced during exposure to dehydration

As an important regulatory mechanism of posttranslation modifications, ubiquitination has been widely recognized as a mechanism to explain how higher plants respond to drought stress $[18,19,28,29]$. In this study,
UPP was significantly enriched in the dehydrationrelated Coral2 module, the transcript level of many genes in UPP showed up-regulation in at least one dehydration treatment group and were significantly downregulated during dehydration (Fig. $2 \mathrm{~d}$ and Table 2). We therefore suggest that UPP may have played an important role in the dehydration-response of G. furcata.

Growing evidence indicates that UPP has a functional role of tolerating abiotic stress in those seaweeds studied this far, despite most of these studies focusing on heat shock stress [30-33]. A study of the red alga Gracilaria lemaneiformis demonstrated that the bioactivity of UPP was directly related to its ability to withstand heat stress [33]. Nevertheless, research linking UPP to dehydration in macroalgae are still very scarce. One study of dehydration-tolerant seaweed Fucus vesiculosus reported on the over-expression of two ubiquitin-ribosomal protein fusion genes, thereby suggesting that the protein targeting and degradation pathway, via $26 \mathrm{~S}$ proteasome, was up-regulated during dehydration [34]. Another 
study of the high intertidal red seaweed, $P$. orbicularis showed a significant increase of the transcript level of ubiquitin during water loss and down regulation during rehydration [5]. The results presented here on the intertidal red alga G. furcata further support the viewpoint that, as with higher plants, ubiquitin production is also a crucial mechanism for exposed seaweeds to adapt to periodic dehydration stress during low tides.

Ubiquitin-activating enzymes (E1), ubiquitinconjugating enzymes (E2) and ubiquitin ligase enzymes (E3), and their concerted actions are required for UPP $[35,36]$. In the dehydration-related module Coral2, six uni-genes encoded different E3 and four of them were found as the hubs in the UPP network (Table 2 and Fig. 3a). This was taken to indicate that diverse kinds of E3 exist in G. furcata and likely play vital functions in UPP. In fact, E3 are the most diverse enzymes in the ubiquitin proteasome system and have been divided into many different types based on sub-unit compositions (e.g. HECT type, F-box type, RING type, U-box type) [36]. E3 determine the specific selection and recognition of substrate proteins in UPP [35, 37], the fact that E3 interact with different targets accounts for making them important hubs in UPP network.

In G. furcata, we found one candidate dehydrationinduced E3 (E3-1) significantly responded to water loss because its expression increased markedly at FD4.5, FD6.0 and SD6.0 (Fig. 5). We propose that E3 positively responding to water deficit and resisted the negative influences caused by exposure to dehydration. In fact, many types of E3 have been identified in higher plants to participate in tolerating drought stress by reducing oxidative stress and regulating downstream genes (e.g. drought-related transcription factors) [38-41]. Our study is the first report of an E3 expression profile significantly associated with a dehydration response in macroalgae. Similarly, differential expression analysis in the red intertidal macroalga, Pyropia haitanensis showed that long-term exposure to high temperature, another major abiotic stress for intertidal seaweeds, also induced the expression of E3 [42].

In addition to E3, another hub gene SAE2 related to SUMOylation also showed high connectivity with other genes in the UPP network, with an almost 7-10 fold increment at different time points of the dehydration treatment (Table 2 and Fig. 5). Such a pattern enabled us to argue that SAE2 also played an important role in dealing with the stresses of water loss. SAE2 is an essential large sub-unit for the SUMO-activating enzyme (SAE) in SUMOlaytion [43].SUMOlaytion is another important form of post-translational modification similar to UPP, which also plays crucial roles in regulating what when responding to abiotic stress responses, particularly in plant drought stress [44-46]. Some studies suggest that SAE may act as a limiting regulatory step during SUMO conjugation [43, 47]. It was found that when SUMO conjugation was impaired by the expression of the SAE2 ${ }^{\text {UFDCt }}$ domain, plants became more sensitive to drought [48].

\section{PI signal connected with $\mathrm{Ca}^{2+} / \mathrm{CaM}$ pathway responded to dehydration, and the role of CaM and ITPK in signal transduction}

When land plants are faced with abiotic stresses, timely signal transmission can activate response mechanisms which enable them to respond and resist $[49,50]$. The PI signal system, including a series of kinases and phosphatases, is involved in the perception and transduction of external stimuli $[49,51]$. In this study, the PI signal pathway showed a significant enrichment in the dehydration-related module, supporting its crucial function during water loss in G. furcata (Fig. 2d).

The PI signal also interacted with the $\mathrm{Ca}^{2+} / \mathrm{CaM}$ signal pathway $[49,51,52]$. Here, CaM is an essential part of the $\mathrm{Ca}^{2+} / \mathrm{CaM}$ signal [53], and showed the highest connectivity in the PI signal network, its expression was affected by water loss during both of the periodic dehydration treatments (Figs. 4a and 5). These results suggested that for intertidal seaweeds, the PI signal pathway most likely interacts with $\mathrm{Ca}^{2+} / \mathrm{CaM}$ signals in order to construct a complex signal regulatory network for transducing external stress signals and activating downstream pathways in response to dehydration.

$\mathrm{CaM}$ is an ubiquitous $\mathrm{Ca}^{2+}$-binding protein related to many biochemical reactions, and can be activated by $\mathrm{Ca}^{2+}$ release in response to multiple environmental stimuli [53]. The intertidal red seaweed Porphyra yezoensis also increased the expression level of the CaM gene when loss of tissue water reached $20 \%$, the expression peaked when reaching 40\% [54]. Likewise, CaM showed an increased transcription level in $P$. orbicularis during dehydration and returned to the normal levels when rehydrated [5]. This environment-induced change of $\mathrm{CaM}$ has also been reported under copper and temperature stresses in other seaweeds $[55,56]$.

Although the PI signal pathway is associated with the $\mathrm{Ca}^{2+} / \mathrm{CaM}$ signal pathway in stress-induced signal networks, how they interact with each other is still largely unknown. One connection between these two pathways is through the secondary messenger inositol 1,4,5-trisphosphate $\left[\right.$ Ins $(1,4,5) \mathrm{P}_{3}$ ], generated by PLC hydrolysis $[49,51,57,58]$. Ins $(1,4,5) \mathrm{P}_{3}$ can release $\mathrm{Ca}^{2+}$ from the endoplasmic reticulum (ER) to change the concentration of $\mathrm{Ca}^{2+}$ and regulate downstream mechanisms with activated CaM $[49,51,57]$. In turn, the activities of PLC can be stimulated by higher $\mathrm{Ca}^{2+}$ concentration $[58,59]$. Our results from G. furcata, however, do not seem to support this viewpoint. Although one hub gene 
(Gf14233) in the PI network annotated as PLC by KOID, but the expression level of PLC was not affected significantly by water loss (Fig. 4a, Table 2). Actually, genes encoding for the Ins $(1,4,5) \mathrm{P}_{3}$ receptor have not been found in plants [60]. More importantly, the pleckstrin homology $(\mathrm{PH})$ domain and $\mathrm{EF}$ hand, the important structural domains for membrane binding and $\mathrm{Ca}^{2+}$ dependent activation of PLC, were reported to be absent in red seaweeds [60].

Another drought-induced hub gene ITPK in the PI signal network (Figs.4a and 5) allows us to propose that the PI signal may connect with the $\mathrm{Ca}^{2+} / \mathrm{CaM}$ pathway by other inositol phosphates in G. furcata. ITPK is the key regulatory enzyme at the branch point for the synthesis of Ins $\mathrm{P}_{4}$ isomers [e.g.Ins $(1,3,4,5) \mathrm{P}_{4}$, Ins $(1,3,4,6)$ $\mathrm{P}_{4}$ and Ins $\left.(3,4,5,6) \mathrm{P}_{4}\right]$, inositol pentakisphosphate $\left(\mathrm{Ins}_{5}\right)$ and inositol hexaphosphate (InsP $\left.\mathrm{P}_{6}\right)$ [61-64]. Recent studies showed that inositol metabolites such as InsP $\mathrm{P}_{6}$ and Ins $(1,3,4,6) \mathrm{P}_{4}$ may also alter cytosol $\mathrm{Ca}^{2+}$ concentration under stress conditions [49, 62, 63]. ITPK can also inter-convert Ins $(3,4,5,6) \mathrm{P}_{4}$ and Ins $(1,3,4,5,6) \mathrm{P}_{5}$ within a substrate cycle to regulate the concentration of Ins $(3,4,5,6) \mathrm{P}_{4}$ [64-66]. Ins $(3,4,5,6) \mathrm{P}_{4}$ can act as the second messenger [67], and play important roles in signal transduction [67-69]. In this study, the dehydrationinduced transcript levels of ITPK indicated it was associated with dehydration stress (Fig. 5) by impacting signal molecules, as reported in many higher plants $[62,63]$. For G. furcata, CaM and ITPK may be at the key position responding to dehydration in terms of a signal transduction network. However, further work is need to verify the potential link between the PI and $\mathrm{Ca}^{2+} / \mathrm{CaM}$ signals by inositol phosphate such as $\operatorname{InsP}_{4}$ and $\mathrm{InsP}_{6}$.

\section{UPP and PI signal co-expression with transcription factor, RNA modification and osmotic regulation related genes}

The PI signal pathway and production of ubiquitin are up-stream regulator systems which can affect many mechanisms dealing with exposure to abiotic stresses $[18,49]$. In G. furcata, we found that many hub genes in these two pathways co-expressed with transcription factors (e.g. sub-units 2 and 6 of TFIID2, TFIIE), RNA modification (e.g. Rrp41-like, DEAH, ZFP) and osmotic regulation-related genes (e.g. ABC1, Bam1, MIP) (Fig. 3b and $4 \mathrm{~b}$ and Table 3 ). Other studies regarding drought tolerance in higher plants also showed that E3 ligase and $\mathrm{CaM}$ could regulate drought stress by interacting with transcription factor and other drought-resistant genes [70-73], providing much support to our results.

The candidate hub-related genes found in our study were mostly elevated to more than 1.5 fold compare to CG at FD 4.5 and FD 6.0, and they exhibited obvious up-regulated trends at SD6.0 compared to FR6.0 (Additional file 10: Fig. S5). Some of them (i.e. DEAH, TFIID,
$\mathrm{ABC1}$, Bam1 and MIP) were reported to link to drought or other abiotic stresses. For example, DEAH was reported to be involved dealing with salt and $\mathrm{Cd}[74,75]$. ABC1 transgenic Arabidopsis thaliana showed an enhanced osmotic regulation ability [76], and $\mathrm{ABC} 1$ is also responsible for oxidative stress [77, 78]. TFIID was proposed a candidate gene for drought response and heat stress in higher plants [79-81], and Bam1 has been reported to participate in drought tolerance by degrading transitory starch to sustain proline $[82,83]$. In addition, MIP in the PI signal network encoded for an aquaporin (AQP) (Fig. 4a), which can maintain cellular water balance under drought conditions and be regulated by a calcium signal [84]. These reports, along with the results from G. furcata, indicated that the ubiquitin mechanism and signal transduction system, including the PI and $\mathrm{Ca}^{2+}$ signals, may influence these drought-related regulator (e.g. TFIID) and osmotic defense genes (e.g. Bam1, MIP) in order to tolerate dehydration.

\section{Conclusions}

The PI signal pathway, connected with the $\mathrm{Ca}^{2+} / \mathrm{CaM}$ signal, is required in order for G. furcatato transduction the external dehydration signal, whilst the ubiquitinrelated pathway provided the post-translation modifications required to cope with dehydration stress in this intertidal red alga. These two pathways served as regulatory mechanisms which may interact with some dehydration-related transcriptional factor, RNA modification, and osmotic regulation genes thereby enabling this seaweed to tolerate considerable water loss at low tide. In these two pathways, E3, SAE2, CaM and ITPK were possibly at the key positions and induced significantly by dehydration. Further research should be conducted related to the complex functions of the ubiquitin mechanism operating in more seaweed species and to provide greater insight into the specific mechanisms of interactions between the PI and $\mathrm{Ca}^{2+} / \mathrm{CaM}$ signals.

\section{Materials and methods}

\section{Plant materials and cultivation conditions}

Specimens of the intertidal red alga G. furcata were collected at April from the upper, rocky intertidal zone in Yantai, Shandong, China $\left(37^{\circ} 27^{\prime} 45.23^{\prime \prime}\right.$ N, $121^{\circ} 26^{\prime} 34.28^{\prime \prime}$ E). We plucked the samples when G. furcata expose to the air during the low tide and all samples were transported to the laboratory with ice. After cleaning the surface with filtered seawater, we selected young and healthy thalli with uniform size and thickness (3-4 months young thalli about $3 \mathrm{~cm}$ long and $1.5 \mathrm{~cm}$ wide) for experiments. Before the formal treatment, according to previous study in G. furcata [26], our samples were pre-cultured at $11^{\circ} \mathrm{C}$ with $50 \mu \mathrm{mol}$ photons $\mathrm{m}^{-2} \mathrm{~s}^{-1}$ 
irradiation provided by cool-white fluorescent lamps in a 12:12 (light:dark) cycle.

\section{Experimental design and sampling}

Considering the semi-diurnal tide in Yantai [85], and the physiological data reported in previous studies [86], we designed two continuous dehydration-rehydration cycles within $24 \mathrm{~h}$ to simulate the natural tidal cycle (Fig. 1). We dried the surface moisture of samples with filter papers and fixed the bottom of the thalli with wooden frame, then suspended individually in a ventilated culture box (GZP-250 N, Shanghai Senxin Co., Ltd., China) for $6 \mathrm{~h}$ as the first dehydration treatment (FD). Samples were taken out at $4.5 \mathrm{~h}$ and $6 \mathrm{~h}$ respectively during FD and immediately frozen in liquid nitrogen and stored at $-80^{\circ} \mathrm{C}$. After $\mathrm{FD}$, the first rehydration treatment (FR) was continued, samples were submerged in the filtered sea water that previously placed at the culture box, and samples were taken out at $5.5 \mathrm{~h}$ and $6 \mathrm{~h}$ successively during FR. During the formal experiment, the temperature was controlled at $11^{\circ} \mathrm{C}$ and the relative humidity was $77 \%$. The treatments during the second dehydration (SD) and second rehydration (SR) were same as FD and FR mentioned above, and samples were taken out at 4.5 and $6 \mathrm{~h}$ during SD and $6 \mathrm{~h}$ during SR. The G. furcata were sampled at eight different time points during two dehydration-rehydration cycles, for convenience, the eight time points were abbreviated as CG (control group), FD4.5, FD6.0, FR5.5, FR6.0, SD4.5, SD6.0, SR6.0. At each time point we prepared more than three biological replications.

RNA extraction, sequencing and transcriptome assembly Total RNA was extracted from the thalli using the Plant RNA Kit 150 (Omega, USA) according to the manufacturer's instructions. RNA degradation and contamination were monitored on $1 \%$ agarose gels and NanoPhotometer spectrophotometer (DeNovix, USA). As described above, we designed eight time points for RNA sequencing, and each had three biological replications. A total of 24 Seq-libraries were sequenced on Illumina HiSeq2000 instrument (Guangzhou Gene Denovo Biotechnology Co., Ltd., China). The raw reads were filtered by removing reads with adapters, reads with a ratio of $\mathrm{N}$ (the percentage of nucleotides in the reads that could not be sequenced) $>10 \%$ and low-quality reads (those reads containing over $40 \%$ bases with $Q$ value $<20 \%$ ), reads that mapped toribosome (rRNA) were also removed. For normalization of the data, gene expression levels were measured by the number of uniquely mapped reads per kilobase of exon region per million mapable reads (RPKMs).

\section{WGCNA analysis and network construction}

For WGCNA (co-expression network analysis), unigenes obtained from RNA-sequencing were filtered for a second time. Genes with RPKM $<1$ in all samples or the coefficient of variation $\left[(\mathrm{SD} / \text { Mean })^{*} 100 \%\right]<0.1$ were removed. All the remaining uni-genes were used for WGCNA with R-package [87]. According to the correlations between genes, the co-expression adjacency matrix was formed and converted to a topological overlap matrix (TOM). Co-expression modules were generated by hierarchical clustering and a dynamic tree cut, the minimum module size was set as 50 and modules with a tree height $<0.3$ were merged together. The expression patterns of 20 modules were displayed as the eigenvalues (equivalent to the weighted synthesis values of all genes in each module and can reflect the comprehensive expression level for the module) [88]. The Coral2 modulebased networks for UPP and PI signal pathways were constructed using genes annotated into these pathways as nodes to extract the co-expressed gene pairs. The resulting networks, with an edge weight cut off of 0.45 (for PI signal network) or 0.4 (for UPP network), were visualized by Cytoscape [89]. The hub genes are those showing the most connections in the network and often play important roles. In our study, genes which had degree values between 100 and 150 were considered as mid-size hubs, those genes with degree values $>150$ were considered as large hubs.

\section{Gene annotation and pathway enrichment analysis}

Description of uni-genes and pathway annotation were performed by BLASTing databases, including the Kyoto Encyclopedia of Genes and Genomes database (KEGG, http://www.genome.jp/kegg), Clusters of Orthologous Groups of proteins (KOG, http://www.ncbi.nlm. nih.gov/COG/KOG), NCBI non-redundant protein sequences (Nr, http://www.ncbi.nlm.nih.gov) and Swissprot (http://www.expasy.ch/sprot). In addition, GO analyse and KEGG enrichment test were also used to detect potential dehydration responsive function between co-clustered genes in the dehydration-related module. Pathways with $P$ value $<0.05$ were considered as significant enrichment.

\section{Gene expression analysis by qRT-PCR}

RNA used for qRT-PCR was the same as that for previous transcriptome sequencing. For the first-strand cDNA synthesis, the PrimeScript ${ }^{\mathrm{tm}}$ RT Regen Kit with gDNA Eraser Kit (Takara, Kyoto, Japan) was used following the manufacturer's instructions. The expression levels of selected genes were verified by qRT-PCR with the following cycling conditions: $95^{\circ} \mathrm{C}$ for $30 \mathrm{~s}$, followed by 40 cycles of $95^{\circ} \mathrm{C}$ for $10 \mathrm{~s}, 55^{\circ} \mathrm{C}$ for $10 \mathrm{~s}$ and $72{ }^{\circ} \mathrm{C}$ for $20 \mathrm{~s}$. The qRT-PCR was conducted using SYBR ${ }^{\circ}$ Premix 
Ex Taq ${ }^{\text {Ta }}$ II (Tli RNaseH Plus, Takara, Kyoto, Japan). The reactions were performed in $20 \mu \mathrm{L}$ volumes containing $10 \mu \mathrm{L}$ of $2 \times \mathrm{SYBR}^{\circ}$ Premix Ex Taq, $0.8 \mu \mathrm{L}$ of each primer (10 $\mu \mathrm{M}$ concentration of each primer), $3.0 \mu \mathrm{L}$ of the diluted cDNA mix, and $6.4 \mu \mathrm{L}$ of RNA-free water. A melting curve for each amplicon was then analyzed to verify the specificity of each amplification reaction. No template controls were included for each primer pair and each PCR reaction was carried out in three biological replicates. Elongation factor 2 (EF2) were used as internal controls [90, 91], and the sequence of EF2 was obtained in NCBI (GenBank: EF033553.1). The $2^{-\triangle \Delta C t}$ method was used to calculate relative gene expression values. The sequences of the primers used are given in Additional file 11: Table S6, the primers concentrations were $10 \mu \mathrm{M}$.

\section{Supplementary information}

Supplementary information accompanies this paper at https://doi.org/10. 1186/s12870-019-2125-z.

Additional file 1: Table S1. The number of reads and identified unigenes in each sample.

Additional file 2: Fig. S1. Statistics for the number of genes with different RPKM values in each library.

Additional file 3: Fig. S2. Venn diagram of the annotation of uni-genes in four databases.

Additional file 4: Table S2. The qRT-PCR results of uni-genes for testing transcriptome data.

Additional file 5: Fig. S3. Hierarchical clustering of the topological overlap matrix (TOM) of genes.

Additional file 6: Fig. S4. Summary of GO terms in Coral 2.

Additional file 7: Table S3. Table of Coral2 uni-genes annotated to KEGG pathway of protein export, starch and sucrose metabolism.

Additional file 8: Table S4. Table of all nodes in the UPP network. Additional file 9: Table S5. Table of all nodes in the PI signal network. Additional file 10: Fig. S5. Broken line chart of the candidate hubinteracted genes.

Additional file 11: Table S6. Table of primer sequence used in this study.

\section{Abbreviations \\ AQP: aquaporin; E3: Ubiquitin ligase E3; FD: First dehydration treatment; FR: First rehydration treatment; GO: Gene ontology; KEGG: Kyoto encyclopedia of genes and genomes; KME: Eigengene-based connectivity; PI: Phosphatidylinositol; qRT-PCR: quantitative reverse transcription PCR; ROS: Reactive oxygen species; RPKM: reads per kilobase of exon region per million mapped reads; SD: Second dehydration treatment; SR: Second rehydration treatment; SUMO: Small ubiquitin-related modifier; TOM: Topological overlap matrix; UPP: Ubiquitin-mediated proteasome pathway; WGCNA: co-expression network analysis}

\section{Acknowledgements}

We thank Gene Denovo Biotechnology co. LTD (Guangzhou, China) for giving the support of RNA-sequencing technical services. Special thanks go to Dr. Claire Gachon (Scottish Association for Marine Science, Scottish Marine Institute) for providing valuable comments on experimental design.

\section{Authors' contributions}

SL was responsible for the RNA extraction and data analysis. SL drafted the manuscript, ZMH and DLD revised it. ZMH, QSZ and DLD conceived the study. ZMH, QSZ and XQY participated in collection of G. furcata samples and incubation in the laboratory. ATC helped with the English revision. All authors contributed to and approved the final manuscript.

\section{Funding}

This research was supported by National Natural Science Foundation of China (41761144057) and Marine S\&T Fund of Shandong Province for Pilot National Laboratory for Marine Science and Technology (Qingdao) (No. 2018SDKJ0502-1).

Availability of data and materials

All datasets generated or analyzed during this study are available from the corresponding author on reasonable request.

Ethics approval and consent to participate

Not applicable.

\section{Consent for publication}

Not applicable.

\section{Competing interests}

The authors declare that they have no competing interests.

\section{Author details}

'Key Laboratory of Experimental Marine Biology, Center for Ocean Mega-Science, Institute of Oceanology, Chinese Academy of Sciences, Qingdao 266071, People's Republic of China. ${ }^{2}$ Laboratory for Marine Biology and Biotechnology, Qingdao National Laboratory for Marine Science and Technology, Qingdao 266071, People's Republic of China. ${ }^{3}$ University of Chinese Academy of Sciences, Beijing 100049, People's Republic of China.

${ }^{4}$ Ocean School, Yantai University, Yantai 264005, People's Republic of China. ${ }^{5}$ Verschuren Centre for Sustainability in Energy and Environment, University of Cape Breton, Sydney, Nova Scotia, Canada.

Received: 18 February 2019 Accepted: 8 November 2019

Published online: 27 November 2019

\section{References}

1. Davison IR, Pearson GA. Stress tolerance in intertidal seaweeds. J Phycol. 1996;32(2):197-211.

2. Kumar M, Kumari P, Reddy CRK, Jha B. Salinity and desiccation induced oxidative stress acclimation in seaweeds. Adv Bot Res. 2014;71(4):91-123.

3. López-Cristoffanini C, Tellier F, Otaíza R, Correa JA, Contreras-Porcia L. Tolerance to air exposure: a feature driving the latitudinal distribution of two sibling kelp species. Bot Mar. 2013;56:431-40.

4. Flores-Molina MR, María R, Thomas D, Lovazzano C, Núñezc A, Zapatac J, et al. Desiccation stress in intertidal seaweeds: effects on morphology, antioxidant responses and photosynthetic performance. Aquat Bot. 2014; 113:90-9.

5. Fierro C, López-Cristoffanini C, Meynard A, Lovazzano C, Castaneda F, Guajardo $\mathrm{E}$, et al. Expression profile of desiccation tolerance factors in intertidal seaweed species during the tidal cycle. Planta. 2017;245(6):1149-64.

6. Zaneveld JS. Factors controlling the delimitation of littoral benthic marine algal zonation. Am Zool. 1969;9(2):367-91

7. Ji Y, Tanaka J. Effect of desiccation on the photosynthesis of seaweeds from the intertidal zone in Honshu, Japan. Phycol Res. 2002;50(2):145-53.

8. López-Cristoffanini C, Zapata J, Gaillard F, Potin P, Correa JA, ContrerasPorcia L. Identification of proteins involved in desiccation tolerance in the red seaweed Pyropia orbicularis (Rhodophyta, Bangiales). Proteomics. 2015; 15(23-24):3954-68.

9. Dinakar C, Bartels D. Desiccation tolerance in resurrection plants: new insights from transcriptome, proteome and metabolome analysis. Front Plant Sci. 2013;4:482.

10. Burritt DJ, Larkindale J, Hurd CL. Antioxidant metabolism in the intertidal red seaweed Stictosiphonia arbuscula following desiccation. Planta. 2002; 215(5):829-38,

11. Qian F, Luo Q, Yang R, Zhu Z, Chen H, Yan X. The littoral red alga Pyropia haitanensisuses rapid accumulation of floridoside as the desiccation acclimation strategy. J Appl Phycol. 2015;27(1):621-32. 
12. Wang L, Mao Y, Kong F, Cao M, Sun P. Genome-wide expression profiles of Pyropia haitanensis in response to osmotic stress by using deep sequencing technology. BMC Genomics. 2015;16(1):1012.

13. Brawley SH, Blouin NA, Ficko-Blean E, Wheeler GL, Lohr M, Goodson HV, et al. Insights into the red algae and eukaryotic evolution from the genome of Porphyra umbilicalis (Bangiophyceae, Rhodophyta). Proc Natl Acad Sci U S A. 2017;114:E636-E6370.

14. Gao S, Wang G. The enhancement of cyclic electron flow around photosystem I improves the recovery of severely desiccated Porphyra yezoensis (Bangiales, Rhodophyta). J Exp Bot. 2012;63(12):4349-58.

15. Contreras-Porcia L, Thomas D, Flores V, Correa JA. Tolerance to oxidative stress induced by desiccation in Porphyra columbina (Bangiales, Rhodophyta). J Exp Bot. 2011;62(6):1815-29.

16. Holzinger A, Kaplan F, Blaas K, Zechmann B, Komsic-Buchmann K, Becker B. Transcriptomics of desiccation tolerance in the streptophyte green alga Klebsormidium reveal a land plant-like defense reaction. PLoS One. 2014;9: E110630.

17. Guajardo E, Correa JA, Contreras-Porcia L. Role of abscisic acid (ABA) in activating antioxidant tolerance responses to desiccation stress in intertidal seaweed species. Planta. 2016;243(3):767-81.

18. Stone SL. The role of ubiquitin and the 265 proteasome in plant abiotic stress signaling. Front Plant Sci. 2014;5(5):135.

19. Miricescu A, Goslin K, Graciet E. Ubiquitylation in plants: signaling hub for the integration of environmental signals. J Exp Bot. 2018;69:4511-27.

20. Fang Z, Jeong SY, Jung HA, Choi JS, Min BS, Woo MH. Anticholinesterase and antioxidant constituents from Gloiopeltis furcata. Chem Pharm Bull. 2010;58(9):1236-9.

21. Huan L, Gao S, Xie XJ, Tao WR, Pan GH, Zhang BY, et al. Specific photosynthetic and morphological characteristics allow macroalgae Gloiopeltis furcata (Rhodophyta) to survive in unfavorable conditions. Photosynthetica. 2014;52(2):281-7.

22. Chen S, Wu J, Chen L, Zhu C. Effects of light and temperature on the attachment and development of Gloiopeltis tenax and Gloiopeltis furcata tetraspores. J Appl Phycol. 2011;23(6):1045-51.

23. Park SY, Jung BM, Choi YH, Bae SJ. Growth inhibition effects of cancer cell lines by Gloiopeltis furcata fractions in vitro. J Korean Soc Food Sci Nutr. 2005;34:771-5.

24. Yu J, Xu Z, Yan L, Cheng S. Studies on the anti-mutagenic and anti-tumor effects of the polysaccharide of Gloipeltis Furcata. J Shantou Univ. 2007;22: 59-63.

25. Bae SJ, Choi YH. Methanol extract of the seaweed Gloiopeltis furcata induces G2/M arrest and inhibits cyclooxygenase-2 activity in human hepatocarcinoma HepG2 cells. Phytother Res. 2010;21(1):52-7.

26. Liu HL, Li XM, Nan GN, Zhang QS. Photosynthetic activity of Gloiopeltis furcata (intertidal red macroalga) in response to desiccation. J Appl Ecol. 2014;25(5):1491-8.

27. Takei M, Kuda T, Eda M, Shikano A, Takahashi H, Kimura B. Antioxidant and fermentation properties of aqueous solutions of dried algal products from the Boso Peninsula, Japan. Food Biosci. 2017;19:85-91.

28. Guerra D, Crosatti C, Khoshro HH, Mastrangelo AM, Mica E, Mazzucotelli E. Post-transcriptional and post-translational regulations of drought and heat response in plants: a spider's web of mechanisms. Front Plant Sci. 2015;6:57.

29. Sharma B, Joshi D, Yadav PK, Gupta AK, Bhatt TK. Role of ubiquitin-mediated degradation system in plant biology. Front Plant Sci. 2016;7:806.

30. Penna A, Crinelli R, Magnani M. Modulation of the heat shock ubiquitin pool in Skeletonema costatum (Bacillariophyceae). J Phycol. 1996;32(3): 409-15.

31. Liu F, Wang W, Sun $X$, Liang Z, Wang F. RNA-Seq revealed complex response to heat stress on transcriptomic level in Saccharina japonica (Laminariales, Phaeophyta). J Appl Phycol. 2014;26:1585-96.

32. Liu F, Wang W, Sun X, Liang Z, Wang F. Conserved and novel heat stressresponsive microRNAs were identified by deep sequencing in Saccharina japonica (Laminariales, Phaeophyta). Plant Cell Environ. 2015;38(7):1357-67.

33. Li GQ, Zang XN, Zhang XC, Lu N, Ding Y, Gong L, et al. Cloning of ubiquitin-activating enzyme and ubiquitin-conjugating enzyme genes from Gracilaria lemaneiformis and their activity under heat shock. Gene. 2014; 538(1):155-63.

34. Pearson GA, Hoarau G, Lagoleston A, et al. An expressed sequence tag analysis of the intertidal brown seaweeds Fucus serratus (L.) and F. vesiculosus (L.) (Heterokontophyta, Phaeophyceae) in response to abiotic stressors. Mar Biotechnol. 2010;12(2):195-213.
35. Callis J. The ubiquitination machinery of the ubiquitin system. Arabidopsis Book. 2014;12:e0174.

36. Zhang G, Zhang M, Zhao Z, Ren Y, Li Q. Wheat TaPUB1 modulates plant drought stress resistance by improving antioxidant capability. Sci Rep. 2017 ; 7(1):7549

37. Vierstra RD. The expanding universe of ubiquitin and ubiquitin like modifiers. Plant Physiol. 2012;160:2-14.

38. Qin F, Sakuma Y, Tran LS, Maruyama K, Kidokoro S, Fujita Y, et al. Arabidopsis DREB2A-interacting proteins function as RING E3 ligases and negatively regulate plant drought stress-responsive gene expression. Plant Cell. 2008; 20(6):1693-707.

39. Adler G, Konrad Z, Zamir L, Mishra AQ, Raveh D, Bar-Zvi D. The Arabidopsis paralogs, PUB46 and PUB48, encoding U-box E3 ubiquitin ligases, are essential for plant response to drought stress. BMC Plant Biol. 2017;17(1):8.

40. Zhang N, Yin YJ, Liu XY, Tong SM, Xing JW, Zhang Y, et al. The E3 ligase TaSAP5 alters drought stress responses by promoting the degradation of DRIP proteins. Plant Physiol. 2017;175(4):1878-92.

41. Gao S, Song JB, Wang Y, Yang ZM. An F-box E3 ubiquitin ligase-coding gene, AtDIF1, is involved in Arabidopsis salt and drought stress responses in an abscisic acid-dependent manner. Environ Exp Bot. 2017;138:21-35.

42. Wang $W$, Teng $F$, Lin $Y, J i ~ D, X u Y$, , Chen $C$, et al. Transcriptomic study to understand thermal adaptation in a high temperature-tolerant strain of Pyropia haitanensis. PLoS One. 2018;13(4):e0195842.

43. Novatchkova M, Tomanov K, Hofmann K, Stuible HP, Bachmair A. Update on sumoylation: defining core components of the plant SUMO conjugation system by phylogenetic comparison. New Phytol. 2012;195(1):23-31.

44. Mishra N, Srivastava AP, Esmaeili N, Hu W, Shen G. Overexpression of the rice gene OsSIZ1 in Arabidopsis improves drought-, heat-, and salt-tolerance simultaneously. Fish Shellfish Immunol. 2018;13(8):1122.

45. Benlloch R, Maria LL. Sumoylation in plants: mechanistic insights and its role in drought stress. J Exp Bot. 2018;69(19):4539-54.

46. Nurdiani D, Widyajayantie D, Nugroho S. OsSCE1 encoding SUMO E2conjugating enzyme involves in drought stress response of Oryza sativa. Rice Sci. 2018;25(2):73-81.

47. Castaño-Miquel L, Seguí J, Manrique S, Teixeira I, Carretero-Paulet L, Atencio F, Maria Lois L. Diversification of SUMO-activating enzyme in Arabidopsis: implications in SUMO conjugation. Mol Plant. 2013;6(5):1646-60.

48. Castaño-Miquel L, Mas A, Teixeira I, Seguí J, Perearnau A, Thampi BN, et al. SUMOylation inhibition mediated by disruption of SUMO E1-E2 interactions confers plant susceptibility to necrotrophic fungal pathogens. Mol Plant. 2017;10(5):709-20.

49. Zhu JK. Salt and drought stress signal transduction in plants. Annu Rev Plant Biol. 2002:53(53):247-73.

50. Xiong L, Schumaker KS, Zhu JK. Cell signaling during cold, drought, and salt stress. Plant Cell. 2002;14(Suppl):S165-83.

51. Shears SB, Yang L, Qian X. Cell signaling by a physiologically reversible inositol phosphate kinase/phosphatase. Adv Enzym Regul. 2004;44(1):265-77.

52. Munnik T, Vermeer JEM. Osmotic stress-induced phosphoinositide and inositol phosphate signalling in plants. Plant Cell Environ. 2010;33(4):655-69.

53. Yang T, Poovaiah BW. Calcium/calmodulin-mediated signal network in plants. Trends Plant Sci. 2003;8:505-12.

54. Wang MQ, Mao YX, Zhuang YY, Kong FN, Sui ZH. Cloning and analysis of calmodulin gene from Porphyra yezoensis Ueda (Bangiales, Rhodophyta). J Ocean Univ China. 2009:8:247-53.

55. Liu $Y$, Zhang $X$, Sun $H$, Yang $Q$, Zang $X$, Zhang $X$, et al. Cloning and transcription analysis of six members of the calmodulin family in Gracilaria lemaneiformis under heat shock. J Appl Phycol. 2016;28(1):643-51.

56. Contreras-Porcia L, Dennett G, González A, Vergara E, Medina C, Correa JA, et al. Identification of copper-induced genes in the marine alga Ulva compressa (Chlorophyta). Mar Biotechnol. 2011;13(3):544-56.

57. DeWald DB, Torabinejad J, Jones CA, Shope JC, Cangelosi AR, Thompson JE, et al. Rapid accumulation of phosphatidylinositol 4,5-bisphosphate and inositol 1,4,5-trisphosphate correlates with calcium mobilization in saltstressed Arabidopsis. Plant Physiol. 2001;126:759-69.

58. Wu Q, Gao K, Zheng S, Zhu X, Liang Y, Pan J. Calmodulin regulates a TRP channel (ADF1) and phospholipase C (PLC) to mediate elevation of cytosolic calcium during acidic stress that induces deflagellation in Chlamydomonas. FASEB J. 2018;32:3689-99.

59. Hunt L, Otterhag L, Lee JC, Lasheen T, Hunt J, Seki M, et al. Gene-specific expression and calcium activation of Arabidopsis thaliana phospholipase C isoforms. New Phytol. 2004;162(3):643-54. 
60. Mikami K. Structural divergence and loss of phosphoinositide-specific phospholipase $\mathrm{C}$ signaling components during the evolution of the green plant lineage: implications from structural characteristics of algal components. Front Plant Sci. 2014;5:380.

61. Kuo HF, Hsu YY, Lin WC, Chen KY, Munnik T, Brearley CA, et al. Arabidopsis inositol phosphate kinases IPK1 and ITPK1 constitute a metabolic pathway in maintaining phosphate homeostasis. Plant J. 2018;95(4):613-30.

62. Marathe A, Krishnan V, Vinutha T, et al. Exploring the role of Inositol 1,3,4trisphosphate 5/6 kinase-2 (GMITPK2) as a dehydration and salinity stress regulator in Glycine max (L.) Merr. through heterologous expression in $E$. coli. Plant Physiol Biochem. 2017;123:331-41.

63. Du H, Liu L, You L, Yang M, He Y, Li X, et al. Characterization of an inositol 1,3,4-tris phosphate 5/6 kinase gene that is essential for drought and salt stress response in rice. Plant Mol Biol. 2011;77:547-63.

64. Sweetman D, Stavridou I, Johnson S, Green P, Caddick SEK, Brearley CA Arabidopsis thaliana inositol 1,3,4-trisphosphate 5/6-kinase 4 (AtITPK4) is an outlier to a family of ATP-grasp fold proteins from Arabidopsis. FEBS Lett. 2007:581(22):4165-71.

65. Josefsen L, Bohn L, Sørensen MB, Rasmussen SK. Characterization of a multifunctional inositol phosphate kinase from rice and barley belonging to the ATP-grasp superfamily. Gene. 2007;397:114-25.

66. Stiles AR, Qian X, Shears SB, Grabau EA. Metabolic and signaling properties of an Itpk gene family in Glycine max. FEBS Lett. 2008;582(13):1853-8.

67. Shears SB, Ganapathi SB, Gokhale NA, Schenk TMH, Wang H, Weaver JD, et al. Defining signal transduction by inositol phosphates. Subcell Biochem. 2012:59:389-412.

68. Lemtiri-Chlieh F, MacRobbie EAC, Brearley CA. Inositol hexakisphosphate is a physiological signal regulating the K+-inward rectifying conductance in guard cells. Proc Natl Acad Sci. 2000;97:8687-92.

69. Vajanaphanich M, Schultz C, Rudolf MT, Wasserman M, Enyed P, Craxton A, et al. Long-term uncoupling of chloride secretion from intracellular calcium levels by Ins $(3,4,5,6)$ P4. Nature. 1994:371(6499):711-4.

70. Joo H, Lim CW, Lee SC. A pepper RING type E3 ligase, CaASRF1, plays a positive role in drought tolerance via modulation of CaAIBZ1 stability. Plant J. 2018. https://doi.org/10.1111/tpj.14191.

71. Weng H, Yoo CY, Gosney MJ, Hasegawa PM, Mickelbart MV. Poplar GTL1 is a Ca2+/Calmodulin-binding transcription factor that functions in plant water use efficiency and drought tolerance. PLoS One. 2012;7(3):e32925.

72. Lee HK, Cho SK, Son O, Xu ZY, Hwang I, Kim WT. Drought stress-induced Rma1H1, a RING membrane-anchor E3 ubiquitin ligase homolog, regulates aquaporin levels via ubiquitination in transgenic Arabidopsis plants. Plant Cell. 2009:21:622-41.

73. Gilliham M, Dayod M, Hocking BJ, Xu B, Conn SJ, Kaiser BN, et al. Calcium delivery and storage in plant leaves: exploring the link with water flow. J Exp Bot. 2011;62(7):2233-50.

74. Chen J, Wan SB, Liu HH, Fan SL, Zhang YJ, Wang W, et al. Overexpression of an Apocynum venetum DEAD-Box Helicase Gene (AvDH1) in cotton confers salinity tolerance and increases yield in a saline field. Front Plant Sci. 2016;6:1227.

75. Zhang XD, Sun JY, You YY, Song JB, Yang ZM. Identification of Cdresponsive RNA helicase genes and expression of a putative, BnRH 24, mediated by miR158 in canola (Brassica napus). Ecotoxicol Environ Saf. 2018 157:159-68.

76. Wang C, Jing R, Mao X, Chang X, Li A. TaABC1, a member of the activity of bcl complex protein kinase family from common wheat, confers enhanced tolerance to abiotic stresses in Arabidopsis. J Exp Bot. 2011;62(3):1299-311.

77. Yang S, Zeng X, Li T, Liu M, Zhang S, Gao S, et al. AtACDO1, an ABC1-like kinase gene, is involved in chlorophyll degradation and the response to photooxidative stress in Arabidopsis. J Exp Bot. 2012;63(10):3959-73.

78. Jasinski M, Sudre D, Schansker G, Schellenberg M, Constant S, Martinoia E, et al. AtOSA1, a member of the Abc1-like family, as a new factor in cadmium and oxidative stress response. Plant Physiol. 2008;147(2):719-31.

79. Myskow B, Czyczylo-Mysza I, Sokolowska S, Stojalowski S. QTL analysis of moderate drought response in a rye recombinant inbred line (RIL) population shows co-localization of QTIs for morphological and physiological traits. Acta Biol Cracov Ser Bot. 2018;60:59-67.

80. Zanton SJ, Pugh BF. Changes in genome wide occupancy of core transcriptional regulators during heat stress. Proc Natl Acad Sci. 2004; 101(48):16843-8.

81. Ghosh S, Pugh BF. Sequential recruitment of SAGA and TFIID in a genomic response to DNA damage in Saccharomyces cerevisiae. Mol Cell Biol. 2011; 31(1):190-202.
82. Zanella M, Borghi GL, Pirone C, Thalmann M, Pazmino D, Costa A, et al. $\beta$ Amylase 1 (BAM1) degrades transitory starch to sustain proline biosynthesis during drought stress. J Exp Bot. 2016;67(6):1819-26.

83. Monroe JD, Storm AR, Badley EM, Lehman MD, Platt SM, Saunders LK, et al. $\beta$-Amylase 1 and $\beta$-amylase 3 are plastidic starch hydrolases in Arabidopsis that seem to be adapted for different thermal, $\mathrm{pH}$, and stress conditions. Plant Physiol. 2014;166(4):1748-63.

84. Li SZ, Mcdill BW, Kovach PA, Ding L, Go WY, Ho SN, et al. Calcineurin-NFATc signaling pathway regulates $A Q P 2$ expression in response to calcium signals and osmotic stress. Am J Phys Cell Phys. 2007;292(5):C1606-16.

85. Lei H. Study on tidal wave properties in the marginal seas adjacent to Yantai. J Dalian Marit Univ. 2006;32(3):33-6.

86. Chen SW, Chen LX, Zhu C, Li S. Effects of environmental factors on growth and survival of Gloiopeltis furcata thalli. S China Fish Sci. 2014;10(3):92-6.

87. Langfelder P, Horvath S. WGCNA: an R package for weighted correlation network analysis. BMC Bioinformatics. 2008;9:599.

88. Langfelder $\mathrm{P}$, Horvath $\mathrm{S}$. Eigengene networks for studying the relationships between co-expression modules. BMC Syst Biol. 2007;1:54.

89. Lopes CT, Franz M, Kazi F, Donaldson SL, Morris Q, Bader GD. Cytoscape web: an interactive web-based network browser. Bioinformatics. 2010;26(18): 2347-8.

90. Jing $C$, Chen $L, X u Y$, Ji D, Chen $C$, Xie C. Selection of the internal control gene for expression analyses of Pyropia haitanensis under high light stress by quantitative real-time PCR. J Fish China. 2017;41(7):1064-72.

91. Lves-Lima C, Cavacana N, Chaves GAT, de Lima NO, Stefanello E, Colepicolo $P$, et al. Reference genes for transcript quantification in Gracilaria tenuistipitata under drought stress. J Appl Phycol. 2017;29(2):731-40.

\section{Publisher's Note}

Springer Nature remains neutral with regard to jurisdictional claims in published maps and institutional affiliations.

\section{Ready to submit your research? Choose BMC and benefit from:}

- fast, convenient online submission

- thorough peer review by experienced researchers in your field

- rapid publication on acceptance

- support for research data, including large and complex data types

- gold Open Access which fosters wider collaboration and increased citations

- maximum visibility for your research: over $100 \mathrm{M}$ website views per year

At BMC, research is always in progress.

Learn more biomedcentral.com/submissions 